\title{
Expression and purification of full-length Alanyl-tRNA-synthetase from Thermus thermophilus HB27
}

\author{
M. Yu. Rybak ${ }^{1}$, A. E. Priss ${ }^{1}$, O. I. Gudzera ${ }^{1}$, A. O. Kovalchuk², \\ I. A. Kryklyvyi ${ }^{1}$, M. A. Tukalo ${ }^{1}$ \\ ${ }^{1}$ Institute of Molecular Biology and Genetics, NAS of Ukraine \\ 150, Akademika Zabolotnoho Str., Kyiv, Ukraine, 03143 \\ ${ }^{2}$ ESC "Institute of Biology and Medicine", Taras Shevchenko National University of Kyiv \\ 64/13, Volodymyrska Str., Kyiv, Ukraine, 01601 \\ mariia.rybak@gmail.com
}

\begin{abstract}
Aim. To gain insight into structural and functional properties of alanyl-tRNA,synthetase (AlaRS), we genetically engineered constructs for expression and purification of full-length AlaRS and checked its activity in aminoacylation assays. Methods. The genomic DNA for the AlaS gene from the T. thermophilus (HB 27 strain) was amplified by PCR and cloned into vectors with and without a histidine tag. To optimize conditions for the protein expression in E.coli and to develop efficient purification procedure, the molecular biology techniques were applied. AlaRS was purified by affinity and size-exclusion chromatography. The molecular weight of enzyme was determined by gel filtration. Results. The expression and purification conditions for recombinant AlaRS were optimized. Approximately $1.5 \mathrm{mg}$ of the pure active recombinant enzyme can be obtained from $1 \mathrm{~L}$ of bacterial culture. AlaRS from T. thermophilus is a dimer in solution with an experimental MW of $204 \mathrm{kDa}$. Conclusions. The purified recombinant enzyme will be used for further studies on the functional kinetics and structure of the crystal complex with tRNA.
\end{abstract}

Key word s: aminoacyl-tRNA-synthetase, AlaRS from T. thermophilus, expression of recombinant protein, protein purification.

\section{Introduction}

Aminoacyl-tRNA-synthetases (aaRSs) attach cognate amino acids (aa) to their tRNAs in a two-step reaction: 1) the activation of amino acid with ATP (generation of aa-AMP) and 2) the transfer of activated amino acid to the 3'-end of
tRNA (formation of aminoacyl-tRNA) [1, 2]. By different functional and structural features, these enzymes were divided into classes I and II [3-5]. Alanyl-tRNA synthetase (AlaRS) belongs to class II and consists of four domains: the N-terminal (aminoacylation domain), editing one, the domain of tRNA recognition and the

(C) 2018 M. Yu. Rybak et al.; Published by the Institute of Molecular Biology and Genetics, NAS of Ukraine on behalf of Biopolymers and Cell. This is an Open Access article distributed under the terms of the Creative Commons Attribution License (http://creativecommons.org/licenses/by/4.0/), which permits unrestricted reuse, distribution, and reproduction in any medium, provided the original work is properly cited 
C-terminal domain, responsible for oligomerization [6]. The C-Ala domain also has a subdomain, which plays an essential role in aminoacylation and editing [7]. In different organisms, AlaRS may have a quaternary structure of tetramer (Escherichia coli) [8] or dimer (Thermus thermophilus HB8) [9], or exist as a monomer (Bombyx mori) [10]. Noteworthy, this synthetase has a special history of study: on the one hand, AlaRS from E. coli is the first synthetase that was cloned, sequenced [11], characterized genetically [12] and biochemically [13, 14], on the other hand, only after 25 years of research the first crystal structure of AlaRS was resolved for the 453-aa N-terminal catalytic fragment of the Aquifex aeolicus enzyme [15]. Then the 441-aa catalytic fragment of E.coli AlaRS with different leucine-zipper surface mutations in the complex with glycine, L-alanine and L-serine was reported [16]. Later the modified leucine halfzipper technique [17] was used for the E.coli AlaRS and the interactions between tRNA ${ }^{\text {Ala }}$ and the synthetase were studied by ITC (Isothermal Titration Calorimetry) [18].

The alanyl-system is also interesting in its recognition context. tRNA Ala contains a unique wobble G3:U70 base pair in the acceptor stem which determines its specificity to AlaRS [19]. Recently, the first complex of archaeon AlaRS catalytic fragment from Archaeoglobus fulgidus has been reported in 2 states - with tRNA ${ }^{\text {Ala }}$ bearing G3.U70 and with variant A3·U70 [20]. Interestingly, human AlaRS was identified to be able to mischarge G4:U69tRNA, possessing an evolutionary gain-offunction and not being an accidental mistake [21]. The human C-Ala domain evolutionarily lost its prokaryotic tRNA functional role [7] on editing and aminoacylation and is remolded into the DNA-binding protein [22]. Recently, Chong et al. have reported three different strategies in the G3:U70 recognition among kingdoms of life [23]. On the other hand, it was shown for E.coli AlaRS that G3:U70 pair is an important element for specific interaction with the editing domain of the enzyme [19]. Thus, the precise recognition mechanism abides disputable until the spatial structure of full-length AlaRS with tRNAAla is solved.

Despite the progress in the field, the mechanisms of aminoacylation and editing by AlaRS remain unknown; the observations of functional and structural properties of synthetases from all kingdoms of life are still relevant. In this study we cloned AlaRS from the T. thermophilus HB27 strain (AlaRSTT), developed and compared purification technique of enzyme with and without C-terminal 6-histidine-tag, resulted in a fast 2-step purification procedure.

\section{Materials and Methods}

Cloning of alaS gene. Genomic DNA from $T$. thermophilus cells was obtained according to [24]. Based on the sequence information of alaS from Thermus thermophilus strain HB27 (P61707 in UniProt [25] and WP_011173855.1 in GenBank [26], 882 amino acid residues) a pair of primers was designed for PCR: 5' forward - atatgcgcacggcggagatccgcgagaagttcc and 5' reverse - aagettattaggggaggaggccggggagggectccegg, which contained NdeI and HindIII restriction sites (marked respectively). Long-PCR-mix (Pfu+Taq) was used for gene amplification. PCR product was gel purified and further cloning proceeded according to TOPO TA protocol («Invitrogen», USA) into the pCR2.1 vector. Briefly, $6 \mu 1$ of mixture, consisted of $2 / 3$ volume of purified PCR pro- 
duct, $1 / 6$ - pCR2.1 vector, $1 / 6$ - salt solution (200 mM NaCl, $10 \mathrm{mM} \mathrm{MgCl}$ ), was incubated at $37^{\circ} \mathrm{C}$ for $10 \mathrm{~min}$. Electrocompetent Top10 E.coli cells («Invitrogen», USA) were used for the transformation («Bio-Rad» electroporation system). The blue-white screening was performed for selection of $\mathrm{Kan}^{\mathrm{R}}$ and $\mathrm{Amp}^{\mathrm{R}}$ clones with further restriction analysis for target gene (about 2646bp) detection. Positive clones were confirmed by NcoI and HindIII restriction and visualized on $1.5 \%$ agarose gel. The correct sequence of AlaRSTT gene was confirmed by DNA sequencing.

To create the His-tagged protein construction, C-terminal linker, encoding 6 histidine residues, was added in PCR with 2 primers: 5'-ctccceggcctcctcccctataagcttgcggccgcactcg-3' (AlaRSTT-6His-1) and 5'-cgagtgcggccgcaagcttataggggaggaggecggggag-3' (AlaRSTT-6His-2).

Then both AlaRSTT constructions (with and without His-tag) were excited by NcoI and Hind III Fast Digest («Thermo Scientific») restrictases and ligated into the $\mathrm{pET} 28 \mathrm{~b}$ vector, previously dephosphorylated by 1 unit of shrimp phosphatase in $1^{\mathrm{X}}$ reaction buffer («Roche»). Ligation proceeded with 1 unit of T4-DNA-ligase in $1^{\mathrm{X}}$ ligase buffer («Thermo Scientific») for $20 \mathrm{~h}$ at $14^{\circ} \mathrm{C}$, followed by Top10 electroporation and sequencing.

\section{A small-scale test of AlaRSTT expression}

The E.coli BL21(DE3)Star cells were electroporated with pET28b-AlaRS/His-AlaRS plasmid. The analysis of the expression level was performed in $\mathrm{P}$ (phosphate), LB (Lauria-Broth) and TB (Terrific-Broth), supplemented with kanamycin $(50 \mu \mathrm{g} / \mathrm{ml})$. Pre-culture $(2 \mathrm{ml})$ was grown overnight at $37^{\circ} \mathrm{C}$. Culture $(10 \mathrm{ml}$ of each medium) was inoculated by pre-culture in 1:100 dilution, at $\mathrm{OD}_{600}=0.6$ the protein expression was induced by $1 \mathrm{mM}$ IPTG for $3 \mathrm{~h}$. Cells were harvested by centrifugation $(10 \mathrm{~min}, 6000 \times \mathrm{g}$ at $4{ }^{\circ} \mathrm{C}$ ) and resuspended in $50 \mathrm{mM}$ Tris- $\mathrm{HCl}, \mathrm{pH}$ 8.0, $5 \mathrm{mM}$ EDTA, $4 \%$ glycerol, $20 \mathrm{mM}$ $\beta$-mercaptoethanol, $1^{\mathrm{x}}$ cocktail of protease inhibitors («Roche»), $0.5 \mu \mathrm{g} / \mu \mathrm{l}$ lysozyme, followed by 2 cycles of freezing/defrosting $\left(80^{\circ} \mathrm{C}\right.$, $10 \mathrm{~min})$. To reduce the viscosity, $25 \mathrm{mM} \mathrm{MgCl} 2$ and $1 \mathrm{u} / \mu 1$ DNase I were added and left for $15 \mathrm{~min}$ at $37^{\circ} \mathrm{C}$. The lysed cells were centrifuged for $30 \mathrm{~min}$ at $6000 \times \mathrm{g}$. The supernatant (fraction of soluble proteins) was analysed by $10 \%$ PAGE.

Expression of AlaRSTT and strategy of its purification

Pre-culture (50ml) of E.coli BL21(DE3)Star, carrying pET28b-AlaRSTT plasmid, was grown in LB with kanamycin $(50 \mu \mathrm{g} / \mathrm{ml})$ overnight at $37^{\circ} \mathrm{C}$. The cell culture $(1 \mathrm{~L})$ was inoculated with pre-culture and grown to $\mathrm{OD}_{600}=0.6$; after the induction of protein expression with $1 \mathrm{mM}$ IPTG, the culture was grown for 3 hours at $37^{\circ} \mathrm{C}$.

All subsequent steps were conducted at $4{ }^{\circ} \mathrm{C}$. Cells were precipitated at $15000 \mathrm{x}$ g for $20 \mathrm{~min}$. The precipitate was resuspended in a buffer A (20 mM Tris-HCl pH 8.0, 5 mM DTT, $0.1 \mathrm{mM}$ EDTA, $1 \mathrm{mM}$ PMSF, a tablet of a cocktail of protease inhibitors («Roche»)). Lysozyme was added for better cell lysis (to a final concentration of $1 \mathrm{mg} / \mathrm{ml}$ ) and incubated for $30 \mathrm{~min}$. Cells were disrupted by sonication $8 \times 30 \mathrm{sec}$ with $1 \mathrm{~min}$ breaks. The lysate was heated at $70{ }^{\circ} \mathrm{C}$ for $35 \mathrm{~min}$, debris was precipitated by centrifugation at $20000 \times \mathrm{g}$ (30 $\mathrm{min})$. The resulting supernatant was applied to a DEAE-Sepharose column $(30 \mathrm{ml}$, «GE Healthcare»), pre-equilibrated with mo- 
dified buffer A (0.1 mM PMSF and $0.1 \mathrm{mM}$ EDTA) and further washed with it. AlaRSTT was eluted in the linear gradient concentration of $\mathrm{NaCl}$ - from 0 to $350 \mathrm{mM}$. Collected fractions were analysed by Bradford assay and SDS-PAGE. Fractions containing protein were combined and desalted to the $90 \%$ concentration of $\left(\mathrm{NH}_{4}\right)_{2} \mathrm{SO}_{4}(600 \mathrm{~g} / \mathrm{L})$. The precipitate was dissolved in a buffer B $(50 \mathrm{mM}$ Tris- $\mathrm{HCl}$ $\mathrm{pH} 8.0,150 \mathrm{mM} \mathrm{NaCl}, 0.003 \% \mathrm{NaN}_{3}$,) and applied to the pre-equilibrated Hi-Load 16/60 Superdex 200 (150 ml, «Pharmacia Biotech») column with flow rate $0.5 \mathrm{ml} / \mathrm{min}$. The isolated fractions were concentrated on $10 \mathrm{kDa}$ Centricon («Merck») at $6000 \mathrm{rpm}$, analysed spectrophotometrically and electrophoretically, their aminoacylation activity was determined before freezing and storage at $-20{ }^{\circ} \mathrm{C}$.

Final protein concentrations were determined by the Bradford assay using Roti ${ }^{\circledR}$-Quant («Roth») [27]. Light absorption coefficient at $280 \mathrm{~nm}\left(\varepsilon_{280}=93530 \mathrm{M}^{-1} \mathrm{~cm}^{-1}\right)$ and absorbance of $0.1 \%$ solution $\left(\mathrm{A}_{280}(1 \mathrm{mg} / \mathrm{ml})=0.959\right.$ unites $\left.\cdot \mathrm{mg}^{-1} \cdot \mathrm{ml}\right)$ were calculated from the amino acid sequence of the DTDTT (ProtParam tool, ExPASy, Swiss Port) [28] and used for determination of enzyme concentration.

\section{His-AlaRSTT purification by affinity and} size-exclusion chromatography

The production of His-tagged recombinant protein was performed with $0.6 \mathrm{mM}$ IPTG induction during 3 hours at $37^{\circ} \mathrm{C}$ in P-medium $(1 \mathrm{~L})$. All steps of His-AlaRSTT purification were performed at $4{ }^{\circ} \mathrm{C}$. Harvested cells after $30 \mathrm{~min}$ centrifugation $(15000 \mathrm{x} \mathrm{g})$ were resuspended in buffer C (50 mM Tris-HCl pH 8.0, $300 \mathrm{mM}$ $\mathrm{NaCl}, 1 \mathrm{mM} \beta$-mercaptoethanol, $1^{\mathrm{X}}$ protease inhibitors cocktail («Roche»)), sonicated
$10 \times 30 \mathrm{sec}$ with $1 \mathrm{~min}$ breaks. Then cell debris was precipitated $(20000 \times \mathrm{g}, 30 \mathrm{~min})$, heated in water bath $\left(70^{\circ} \mathrm{C}\right)$, and followed by centrifugation. The concentration of imidazole («Sigma») was adjusted to $15 \mathrm{mM}$ and the clear supernatant was added to Ni-NTA Sepharose Fast Flow resin $(2 \mathrm{ml}$ of $50 \%$ slurry, «GE Healthcare»), pre-equilibrated with the same buffer and incubated for $1 \mathrm{~h}$ at $150 \mathrm{rpm}$. The resin was washed with buffer $\mathrm{C}$, supplemented with $15 \mathrm{mM}$ imidazole followed by washing with solution containing $500 \mathrm{mM} \mathrm{NaCl}$. AlaRSTT was eluted from the column by $250 \mathrm{mM}$ imidazole (as E.coli enzyme [17]). Target protein fractions were combined and dialyzed overnight against $1 \mathrm{~L}$ of buffer $\mathrm{D}$ (50 mM Tris- $\mathrm{HCl} \mathrm{pH} 8.0,5 \mathrm{mM} \mathrm{MgCl}_{2}$ (as recommended for Archaeoglobus fulgidus AlaRS [29]), $1 \mathrm{mM} \beta$-mercaptoethanol), concentrated on $30 \mathrm{kDa}$ Centricon at $6000 \mathrm{rpm}$ to $1 \mathrm{ml}$ volume (4 mg/ml) and loaded to the HiLoad 16/60 Superdex 200 column, pre-equilibrated with buffer $\mathrm{D}$, supplemented with $150 \mathrm{mM} \mathrm{NaCl}, 0.1 \mathrm{mM}$ PMSF, $0.003 \% \mathrm{NaN}_{3}$ ) with flow rate $1 \mathrm{ml} / \mathrm{min}$. Peak fraction was concentrated on $30 \mathrm{kDa}$ Centricon (before concentration this fraction was 3-fold diluted in $1 \mathrm{mM} \beta$-mercaptoethanol and a saturated solution of $\left(\mathrm{NH}_{4}\right)_{2} \mathrm{SO}_{4}$ in proportion 1:20), the purity was analysed by SDS-PAGE.

\section{Gel filtration of proteins}

To access the approximate molecular weight of purified AlaRSTT the size-exclusion chromatography on Hi-Load 16/60 Superdex S 200 was performed. The column was equilibrated with $50 \mathrm{mM}$ Tris- $\mathrm{HCl} \mathrm{pH} 8.0,5 \mathrm{mM} \mathrm{MgCl} 21 \mathrm{mM}$ $\beta$-mercaptoethanol, $150 \mathrm{mM} \mathrm{NaCl}, 0.1 \mathrm{mM}$ PMSF, $0.003 \% \mathrm{NaN}_{3}$. All samples ran at $1 \mathrm{ml} /$ 
min flow rate, the elution was monitored at $280 \mathrm{~nm}$. An elution volume of each protein sample from the column was calculated; the log (MW) of marker proteins was plotted against the ratio $V_{e} / V_{o}$. Marker proteins, which were used for column calibration, are the following: ferritin dimer $(900 \mathrm{kDa})$, ferritin monomer (450 $\mathrm{kDa}), \beta$-amilase (200 kDa), alcohol dehydrogenase $(150 \mathrm{kDa})$, bovine serum albumin $(66 \mathrm{kDa})$, ovalbumin $(45 \mathrm{kDa})$, carboanhydrase $(29 \mathrm{kDa})$ and cytochrome c $(12,4 \mathrm{kDa})$. The molecular weight of AlaRSTT was determined by comparison of its $\mathrm{V}_{\mathrm{e}} / \mathrm{V}_{\mathrm{o}}$ index with those of known protein standards. The calibration curve is shown in Fig. 5.

\section{Test of the aminoacylation activity of purified AlaRSs}

The reaction mixture $(25 \mu \mathrm{l})$ contained $100 \mathrm{mM}$ Tris- $\mathrm{HCl} \mathrm{pH} 7.5,15 \mathrm{mM} \mathrm{MgCl} 2,100 \mu \mathrm{g} / \mathrm{ml}$ BSA, $3 \mathrm{mM}$ ATP, $25 \mu \mathrm{M}\left[{ }^{14} \mathrm{C}\right]$-L-Ala $(158 \mathrm{mCi} /$ mmol; Amersham), $5 \mu \mathrm{g} / \mu \mathrm{l}$ total tRNA, $50 \mathrm{nM}$ AlaRS was conducted at $37{ }^{\circ} \mathrm{C}$ for several minutes. Aliquots were removed from the reaction at appropriate time points, quenched by cold $10 \%$ TCA and passed through nitrocellulose filters. Dried filters were analysed by liquid scintillation counting.

\section{Results and Discussion}

Expression and purification of the fulllength AlaRSTT with problem of its proteolysis

The final protein expression was performed successfully in the LB medium (Fig. 1). Even at the expression step and analysis of protein solubility, we noticed rapid protein degradation, which did not show the dependence on media or buffer composition (Fig.1, 1 - fulllength protein, $2 \mathrm{a} / \mathrm{b}$ - proteolyzed).

The purification procedure combined the anion exhange and size-exclusion chromatographies. The peak fractions, eluted from DEAESepharose with the linear gradient of $\mathrm{NaCl}$ (0-350 mM), were desalted by $\left(\mathrm{NH}_{4}\right)_{2} \mathrm{SO}_{4}$ and uploaded on Superdex 200 column (Fig. 2). During both purification steps, the ratio of fulllength and proteolyzed forms of AlaRSTT remained constant. Despite the including of proteases inhibitors in all solutions, it was impossible to reduce the level of synthetase degradation. We hypothesize that a short form appeared due to the existence of unstable regions of the protein C-terminal domain, which led to the damage and shortening of the target enzyme. This issue seems to be the main reason AlaRSTT has not been crystalized yet, despite the first report of its purification from the

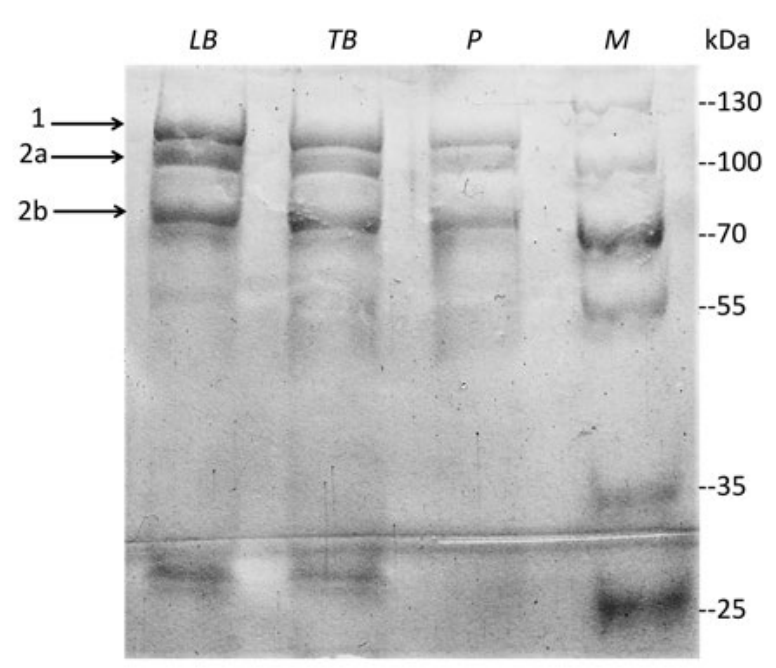

Fig. 1. Test of AlaRSTT expression in LB, TB and P-media after $3 \mathrm{~h}$ of induction with $1 \mathrm{mM}$ IPTG (soluble fraction). $M$-marker (ThermoFisher, PageRuler ${ }^{\mathrm{TM}}$ Prestained Protein ladder 10-170 kDa). 


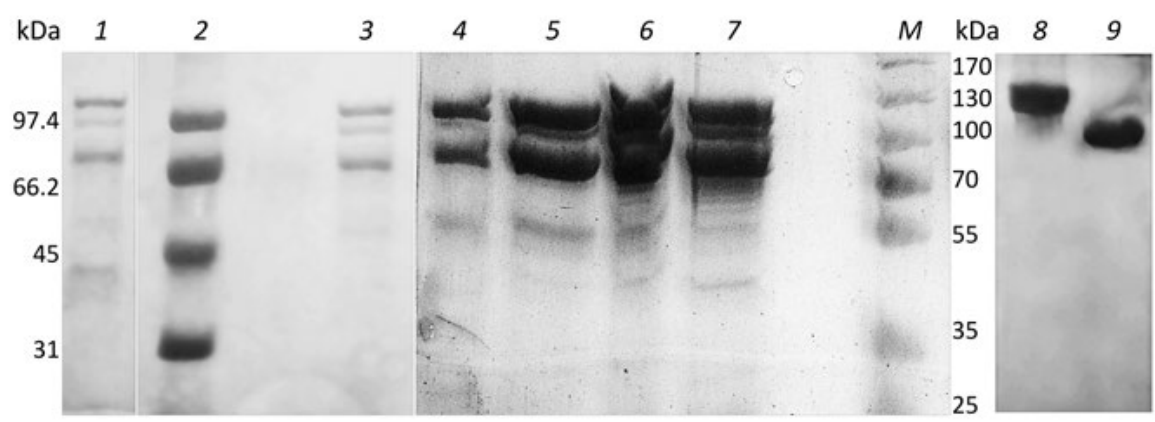

Fig. 2. Purification of AlaRSTT without His-tag by anion exhange and size-exclusion chromatographies. $12.5 \%$ SDSPAGE: 1 - lysate after heating; 2 - protein marker (BioRad LowRange); $3-23^{\text {rd }}$ fraction on DEAE-Sepharose; 4-7 - peak fractions (24-27 respectively) on DEAE-Sepharose, combined for desalting; $M$ - molecular weight marker (ThermoFisher, PageRuler ${ }^{\mathrm{TM}}$ Prestained Protein ladder 10-170 kDa); 8-9 - concentrated AlaRSTT fractions (8-full-length, 9-short) after Superdex 200 column.

T. thermophilus strain HB8 more than 20 years ago [9]. There is no evidence how to overcome this problem, therefore our work is relevant.

Expression and purification of the fulllength AlaRSTT with C-terminal His-tag To overcome the problem with AlaRSTT degradation, we recloned it with $\mathrm{C}$-terminal Histag. Surprisingly, it increased the protein stabi- lity up to $90 \%$. At the first purification step (affinity chromatography on Ni-NTASepharose), only about 5-10 \% of degraded AlaRSTT were observed (Fig. 3). We tried to elute AlaRS with the imidazole gradient, varied concentrations of $\mathrm{NaCl}$ and $\beta$-mercaptoethanol in lysis buffer, adding one more purification step after affinity column (DEAESepharose), but it did not help to eliminate the

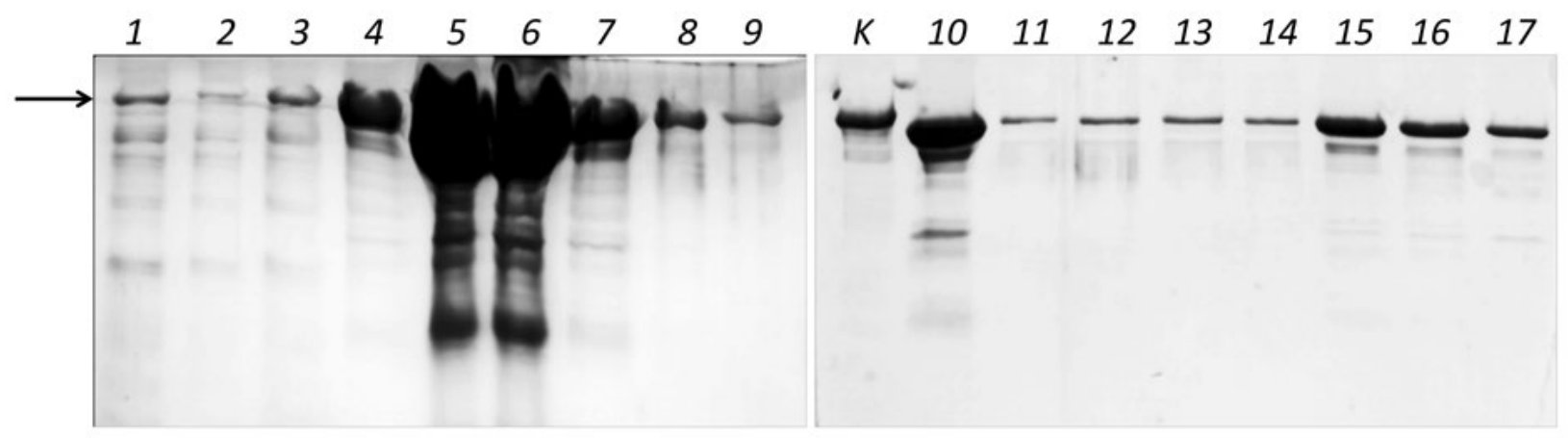

Fig. 3. Two-step purification procedure of His-AlaRSTT: 1 - lysate, uploaded to Ni-NTA-Sepharose column; 2 fraction of proteins, not bound with Ni-NTA; 3 - wash flow-through fraction; 4-9 - peak fractions, eluted from column; $K$ - control, LeuRS from Mycobacterium tuberculosis $(107 \mathrm{kDa}) ; 10$ - combined eluate after dialysis, loaded on Superdex 200 column, 11-17 — fractions on gel-filtration column (1-7 respectively). 

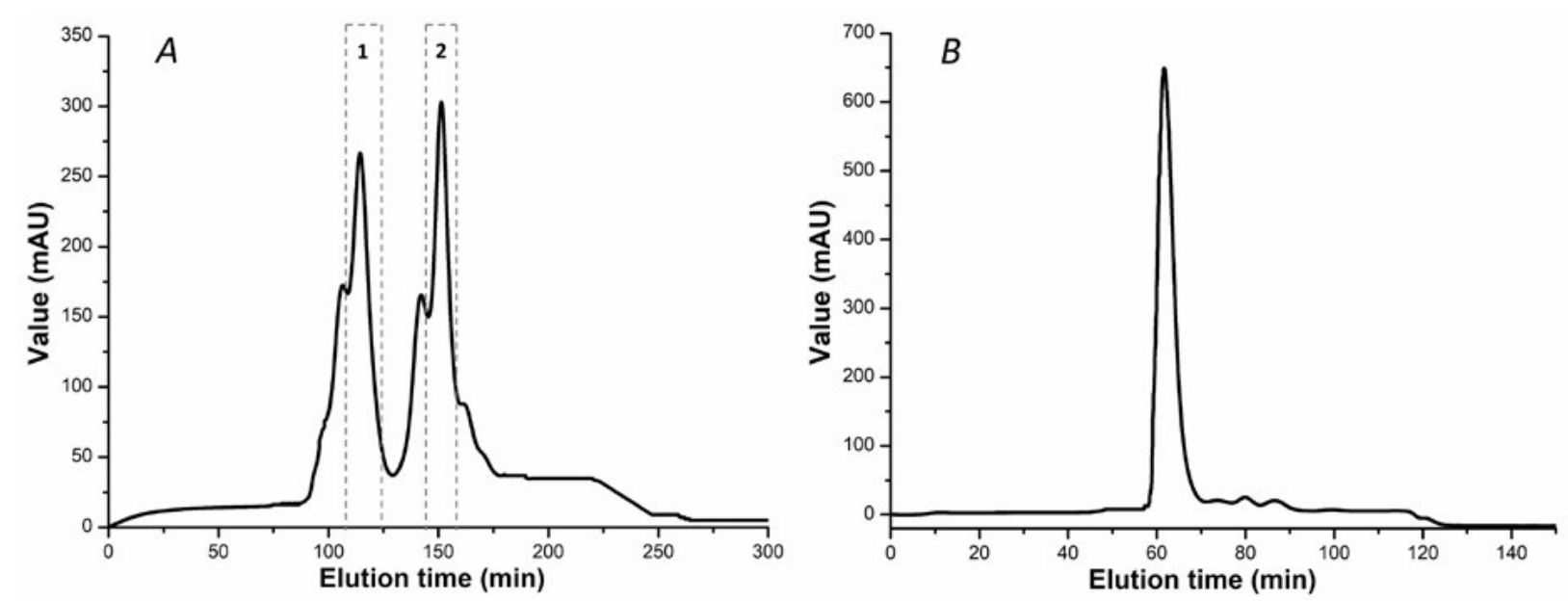

Fig. 4. Purification of AlaRSTT on size-exclusion chromatography on Superdex S 200 column: $A$ - Elution profile for AlaRSTT with flow rate $0.5 \mathrm{ml} / \mathrm{min}$ ( 1 - full-length protein, 2 - its shorten form); $B$ - for $6^{\mathrm{x}}$ His-AlaRSTT with flow rate $1 \mathrm{ml} / \mathrm{min}$.

primary (about $10 \%$ ) protein degradation level (data not shown). Nevertheless, the ratio did not increase after overnight dialysis and the second (size-exclusion) chromatography step (Fig. 4). The elution profile of AlaRSTT on the gel-filtration column is represented in Fig. 4 (A - construct without His, B - with C-terminal $6{ }^{x}$ His-tag). The Fig. 4B profile together with the elution of marker proteins were used for the determination of AlaRSTT molecular weight (MW). The theoretically calculated MW of the corresponding monomer structure was $97.48 \mathrm{kDa}$. Experimentally, it was determined as $204.2 \mathrm{kDa}$, confirming protein dimeric form. Calibration curve is shown in Fig. 5. The total amount of purified protein was $\sim 1.5 \mathrm{mg}$ from $1 \mathrm{~L}$ of bacterial culture ( $\sim 4.2 \mathrm{~g}$ of cell pellet). Thus, our results are comparable with the literature data (Table 1).

Table 1. Comparison of purification steps and total enzyme quantities in T. thermophilus $\mathrm{HB8}$ and $\mathrm{HB} 27$ strains

\begin{tabular}{|l|c|c|}
\hline & Total number of purification steps & Purified protein amount from 1g of E.coli cells (mg) \\
\hline $\begin{array}{l}\text { His-tagged AlaRSTT (strain } \\
\text { HB8) }\end{array}$ & 4 & 0.46 \\
\hline & 2 & $\begin{array}{c}0.72 \\
\text { AlaRSTT (HB27) }\end{array}$ \\
\hline His-tagged AlaRSTT (HB27) & 2 & $\begin{array}{c}\text { b } \\
\text { bull-length; } \\
\text { y }\end{array}$ \\
\hline
\end{tabular}

${ }^{a}$ Literature data, assumed from [9].

${ }^{\mathrm{b}}$ Current study 


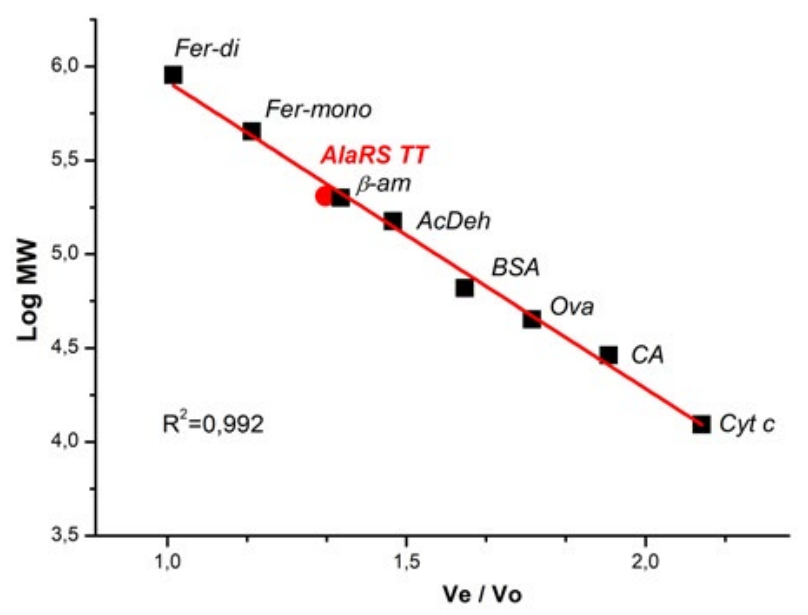

Fig. 5. Determination of AlaRSTT molecular weight by size-exclusion chromatography. Calibration curve on $\mathrm{Su}-$ perdex S 200 column was prepared as described in ,Materials and methods" (Fer-di - ferritin dimer; Fer-mono ferritin monomer; $\beta$-A - $\beta$-amilase; Cat — catalase; AcDeh - alcohol dehydrogenase; BSA — bovine serum albumin; Ova - ovalbumin; AlaRSTT — alanyl-tRNA-synthetase; $\mathrm{CA}$ - carboanhydrase; Cyt.c — cytochrome c)

\section{Aminoacylation activity of purified AlaRSTT}

All purified enzymes were tested for their activity with bulk tRNA from E.coli and ra-

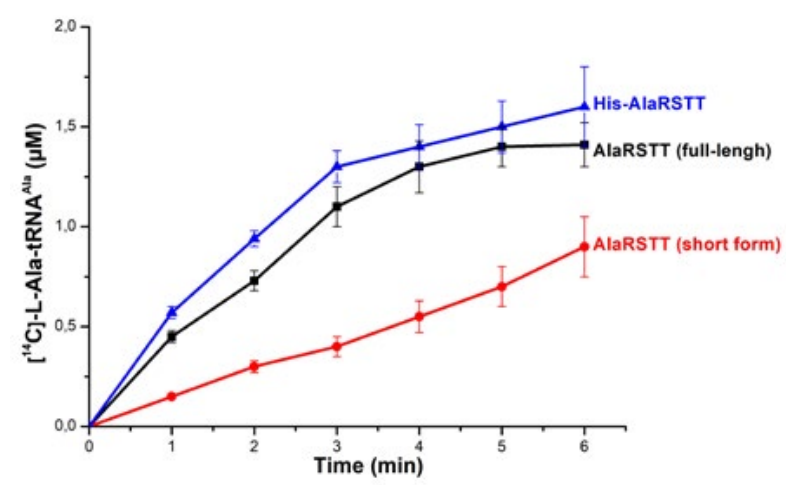

Fig. 6. The initial levels of Ala-tRNA ${ }^{A l a}$ synthesis by AlaRSTT. Experimental details were shown in section "Methods" diolabelled $\left[{ }^{14} \mathrm{C}\right]-\mathrm{L}-\mathrm{Ala}$ (Fig. 6). Noteworthy, the shortened form of AlaRSTT had only a 2-fold less initial velocity in comparison to the full-length protein. Thus, aminoacylation domain of AlaRS (C-Ala) worked properly. The full-length AlaRS has a slightly higher velocity, so it will be used for further functional investigations.

\section{Conclusions}

The recombinant His-AlaRSTT was expressed in E.coli and purified to homogeneity without premixes of degraded forms. For the successful expression and the prevention of protein degradation during purification steps, the affinity tag was attached to the C-end of the target enzyme. AlaRSTT will be used for further structural studies and investigation of its editing mechanism.

\section{Funding}

This work was supported by the National Academy of Sciences of Ukraine (Grant № 0114 U006257).

\section{REFERENCES}

1. Fersht AR, Kaethner MM. Mechanism of aminoacylation of tRNA. Proof of the aminoacyl adenylate pathway for the isoleucyl- and tyrosyl-tRNA synthetases from Escherichia coli K12. Biochemistry. 1976;15(4):818-23.

2. Ibba $M$, Soll D. Aminoacyl-tRNA synthesis. Annu Rev Biochem. 2000;69:617-50.

3. Schimmel P. Classes of aminoacyl-tRNA synthetases and the establishment of the genetic code. Trends Biochem Sci. 1991;16(1):1-3.

4. Eriani $G$, Delarue M, Poch O, Gangloff J, Moras D. Partition of tRNA synthetases into two classes based on mutually exclusive sets of sequence motifs. $\mathrm{Na}$ ture. 1990;347(6289):203-6. 
5. Schimmel PR, Söll D. Aminoacyl-tRNA synthetases: general features and recognition of transfer RNAs. Annu Rev Biochem. 1979;48:601-48.

6. Naganuma M, Sekine S, Fukunaga R, Yokoyama S. Unique protein architecture of alanyl-tRNA synthetase for aminoacylation, editing, and dimerization. Proc Natl Acad Sci U S A. 2009;106(21):8489-94.

7. Guo M, Chong YE, Beebe K, Shapiro R, Yang XL, Schimmel $P$. The C-Ala domain brings together editing and aminoacylation functions on one tRNA. Science. 2009;325(5941):744-7.

8. Putney SD, Sauer RT, Schimmel PR. Purification and properties of alanine tRNA synthetase from Escherichia coli A tetramer of identical subunits. J Biol Chem. 1981;256(1):198-204.

9. Lechler A, Martin A, Zuleeg T, Limmer $S$, Kreutzer $R$. A biologically active $53 \mathrm{kDa}$ fragment of overproduced alanyl-tRNA synthetase from Thermus thermophilus HB8 specifically interacts with tRNA Ala acceptor helix. Nucleic Acids Res. 1997;25(14):2737-44.

10. Dignam SS, Dignam JD. Glycyl- and alanyl-tRNA synthetases from Bombyx mori. Purification and properties. J Biol Chem. 1984;259(7):4043-8.

11. Putney SD, Meléndez DL, Schimmel PR. Cloning, partial sequencing, and in vitro transcription of the gene for alanine tRNA synthetase. $J$ Biol Chem. 1981;256(1):205-11.

12. Jasin M, Regan L, Schimmel P. Modular arrangement of functional domains along the sequence of an aminoacyl tRNA synthetase. Nature. 1983-7; 306(5942):441-7.

13. Wu MX, Filley SJ, Xiong J, Lee JJ, Hill KA. A cysteine in the C-terminal region of alanyl-tRNA synthetase is important for aminoacylation activity. Biochemistry. 1994;33(40):12260-6.

14. Tsui WC, Fersht AR. Probing the principles of amino acid selection using the alanyl-tRNA synthetase from Escherichia coli. Nucleic Acids Res. 1981; 9(18):4627-37.

15. Swairjo MA, Otero FJ, Yang XL, Lovato MA, Skene RJ, McRee DE, Ribas de Pouplana L, Schimmel $P$. Alanyl-tRNA synthetase crystal structure and design for acceptor-stem recognition. Mol Cell. 2004;13(6):829-41.
16. Guo M, Chong YE, Shapiro R, Beebe K, Yang XL, Schimmel P. Paradox of mistranslation of serine for alanine caused by AlaRS recognition dilemma. $\mathrm{Na}$ ture. 2009;462(7274):808-12.

17. Guo M, Shapiro R, Schimmel P, Yang XL. Introduction of a leucine half-zipper engenders multiple high-quality crystals of a recalcitrant tRNA synthetase. Acta Crystallogr D Biol Crystallogr. 2010; 66(Pt 3):243-50.

18. Dignam JD, Guo J, Griffith WP, Garbett NC, Holloway A, Mueser T. Allosteric interaction of nucleotides and tRNA(ala) with E. coli alanyl-tRNA synthetase. Biochemistry. 2011;50(45):9886-900.

19. Beebe K, Mock M, Merriman E, Schimmel P. Distinct domains of tRNA synthetase recognize the same base pair. Nature. 2008;451(7174):90-3.

20. Naganuma M, Sekine S, Chong YE, Guo M, Yang XL, Gamper H, Hou YM, Schimmel P, Yokoyama $S$. The selective tRNA aminoacylation mechanism based on a single G・U pair. Nature. 2014;510(7506):507-11.

21. Sun L, Gomes AC, He W, Zhou H, Wang X, Pan DW, Schimmel P, Pan T, Yang XL. Evolutionary Gain of Alanine Mischarging to Noncognate tRNAs with a G4:U69 Base Pair. J Am Chem Soc. 2016;138(39): 12948-55.

22. Sun L, Song Y, Blocquel D, Yang XL, Schimmel P. Two crystal structures reveal design for repurposing the C-Ala domain of human AlaRS. Proc Natl Acad Sci U S A. 2016;113(50):14300-5.

23. Chong YE, Guo M, Yang XL, Kuhle B, Naganuma M, Sekine SI, Yokoyama S, Schimmel P. Distinct ways of G:U recognition by conserved tRNA binding motifs. Proc Natl Acad Sci U S A. 2018;115(29): 7527-7532.

24. Marmur J. A procedure for the isolation of deoxyribonucleic acid from micro-organisms. Journal Mol Biol. 1961; 3(2): 208-IN1.

25. The UniProt Consortium. UniProt: the universal protein knowledgebase. Nucleic Acids Res. 2017; 45(D1):D158-D169.

26. Benson DA, Karsch-Mizrachi I, Clark K, Lipman DJ, Ostell J, Sayers EW. GenBank. Nucleic Acids Res. 2012;40(Database issue):D48-53.

27. Bradford MM. A rapid and sensitive method for the quantitation of microgram quantities of protein 
utilizing the principle of protein-dye binding. Anal Biochem. 1976;72:248-54.

28. Gasteiger E, Hoogland C, Gattiker A, Wilkins MR, Appel RD, Bairoch A Protein identification and analysis tools on the ExPASy server. The proteomics protocols handbook. Springer. 2005; 571-607.

29. Fukunaga R, Yokoyama S. Crystallization and preliminary X-ray crystallographic study of alanyltRNA synthetase from the archaeon Archaeoglobus fulgidus. Acta Crystallogr Sect F Struct Biol Cryst Commun. 2007;63(Pt 3):224-8.

\section{Експресія та очистка повнорозмірної аланіл- тРНК-синтетази Thermus thermophilus штаму HB27}

М. Ю. Рибак, А. Є. Прісс, О. І. Гудзера, А. О. Ковальчук, І. А. Крикливий, М. А. Тукало

Мета. Для детального вивчення структурних та функціональних властивостей аланіл-тРНК-синтетази (АлаРС) було створено генно-інженерну конструкцію для експресії та очищення повнорозмірної синтетази та перевірено іï активність у реакції аміноацилювання. Методи. Ген AlaS з T. thermophilus (штам HB27) геномної ДНК ампліфікували за допомогою ПЛР з відповідними праймерами та клонували у вектор з та без гістидинової послідовності. Для оптимізації умов експресії білка в E.coli та розробки ефективної процедури очищення були застосовані сучасні методи молекулярної біології. АлаРС очищали методами афінної хроматографії та гель-фільтрації. Молекулярна маса ферменту визначалася на гель-фільтраційній колонці. Результати. Умови експресії та очистки рекомбінантної АлаРС були оптимізовані. Близько 1,5 мг чистого рекомбінантного активного ферменту можна одержати з 1 л бактеріальної культури. АлаРС з T. thermophilus є димером у розчині з експериментальною масою 204 кДа. Висновки. Отриманий рекомбінантний фермент буде використовуватися для подальших експериментів з функціональної кінетики та структурних досліджень кристалічного комплексу з тРНК.
К л ю ч о в і с л о в а: аміноацил-тРНК-синтетаза, АлаРС Т. thermophilus, експресія рекомбінантного білка, хроматографічне очищення білка.

\section{Экспрессия и очистка полноразмерной аланил- тРНК-синтетазы Thermus thermophilus штамма НB27}

М. Ю. Рыбак, А. Е. Присс, О. И. Гудзера, А. А. Ковальчук, И. А. Крикливый, М. А. Тукало

Цель. Для детального изучения структурных и функциональных свойств аланил-тРНК-синтетазы (АлаРС) было создано генно-инженерную конструкцию для экспрессии и очистки полноразмерной синтетазы и проверено ее активность в реакции аминоацилирования. Методы. Ген alaS из геномной ДНК T. thermophilus (штамм НВ27) амплифицировали с помощью ПЦР с соответствующими праймерами и клонировали в вектор с и без гистидиновой последовательностью. Для оптимизации условий экспрессии белка в E.coli и разработки эффективной процедуры очистки были применены современные методы молекулярной биологии. АлаРС очищали методами аффинной хроматографии и гель-фильтрации. Молекулярная масса фермента определялась на гель-фильтрационной колонке.

Результаты. Условия экспрессии и очистки рекомбинантной АлаРС были оптимизированы. Около 1,5 мг чистого рекомбинантного активного фермента можно получить с 1 л бактериальной культуры. АлаРС с T. thermophilus является димером в растворе с экспериментальной массой 204 кДа. Выводы. Полученный рекомбинантный фермент будет использован для дальнейших экспериментов с функциональной кинетики и структурных исследований кристаллического комплекса с тРНК.

К л юч е в ы е с л о в а: аминоацил-тРНК-синтетазы, АлаРС Т. thermophilus, экспрессия рекомбинантного белка, хроматографическое очистки белка.

Received 10.09.2018 